\title{
Women Empowerment through Agriculture in Chapainawabganj, Bangladesh
}

\author{
Mithun Kumar Ghosh, Shaikh Shamim Hasan, Rezuana Fariha, Md. Obaidul Bari and Mst. Arina \\ Parvin
}

\section{ABSTRACT}

\begin{abstract}
Women constitute almost half of the population of Bangladesh and are heavily involved in different agricultural activities though their contributions are neglected as mainstream labor force which hinders their expected development. Considering this fact, the present study was designed to determine the women empowerment through agriculture in Chapainawabganj, a northern district of the country. A pre-structured questionnaire was used to collect data through face to face interview from randomly selected sample size of 120 respondents from four selected village namely Babudying, Hossaindying, Ramjibonpur and Thakurjoubon in Chapainawabganj district. The main findings indicated that about $83.3 \%$ respondents were middle age and $60 \%$ of the respondents were illiterate with $56.7 \%$ belonged to small size family which consists of up to 4 members. Agriculture was the main occupation among the respondents. Most of the respondents were found without own land although they continue their livelihood mostly by crop production, livestock rearing, and day laboring. They take lease $(23.3 \%)$ of cultivable land from others. The respondents had an average monthly family income of about 9351.38 BDT whereas 95\% of the respondents were under medium income category. The respondents had no extension contact $(0 \%)$, having high farming experience $(50 \%)$ and no cosmopolitan behavior $(0 \%)$. Most of the respondents $(\mathbf{7 1 . 7 \%})$ were unable to make their own decision and $33.3 \%$ of the respondents had educational rights. The economic participation rate of the respondents was very high $(100 \%)$, on the other hand they had no economic opportunities $(0 \%)$. The attitude of the respondents towards women empowerment were mostly moderately favorable $(\mathbf{7 0 \%})$. Most of the respondents of the study area were lied between low to medium empowerment $(96.7 \%)$ with minimal high empowerment $(3.30 \%)$. Study suggests that there is need a lot of work for women to improve their present condition. Government and Nongovernment organizations should take proper step to decrease gender discrimination as well as ensure women's fundamental rights to make their life easy and make them more empowered.
\end{abstract}

Keywords: Agriculture, Chapainawabganj, Economic opportunity, Women empowerment.

\section{INTRODUCTION}

Women's empowerment is the process of empowering women [1]. Empowerment is the process that creates power in individuals over their own lives, society, and in their communities. People are empowered if they have access to opportunities without any limitations or restrictions such as in education, profession and in their way of life. Empowerment includes the action of raising the status of women through education, raising awareness, literacy, and training and also give training related to defense our self. Women's empowerment is all about equipping and allowing women to make life-determining decisions through the different problems in society [2]. Women's empowerment is the most crucial point to be noted for the overall development of a country.
Submitted : February 3, 2021

Published : February 24, 2021

ISSN: $2684-1827$

DOI: $10.24018 /$ ejfood.2021.3.1.235

\section{Mithun Kumar Ghosh}

Dept. of Agricultural Extension \& Rural Development, EBAUB, Chapainawabganj, Bangladesh.

(e-mail: mithunbsmrau88@yahoo.com) Shaikh Shamim Hasan*

Dept. of Agril. Extn. \& Rural Devt., BSMRAU, Gazipur, Bangladesh.

(e-mail: shamim.aer@bsmrau.edu.bd)

Rezuana Fariha

Faculty of Agriculture, EBAUB,

Chapainawabganj, Bangladesh.

(e-mail: Rezuanafariha7@gmail.com)

Md. Obaidul Bari

Faculty of Agriculture, EBAUB,

Chapainawabganj, Bangladesh.

(e-mail: mahmudshanto5@gmail.com)

Mst. Arina Parvin

Faculty of Agriculture, EBAUB,

Chapainawabganj, Bangladesh

(e-mail: arinaparvin.ebaub@gmail.com)

*Corresponding Author
Globally $40 \%$ of world's total labor force is women. Sector-wide participation varies for countries and within countries, from $20 \%$ in Latin America to $50 \%$ in parts of Africa and Asia [3].

Bangladesh is a country of high population (144.7 million) with high population density $(964 / \mathrm{km} 2)$ of which women comprises half of the total population of the country [4]-[6]. Even though women percentage is half of the country, but they suffer from different types of penury [7]. Moreover, inconsistencies have been seen in between men and women in Bangladesh in different sectors, like, education, health, employment, income sector, also controlling on the assets and self-security though their role is very crucial inside the home [8], [9]. Agriculture is the chief occupation of women in many parts of Bangladesh. Many ethnic groups such as Santal, Chakma, Garo have been for centuries working as agricultural labor force. The same is also true for many female members of Muslim and Hindus communities [10]. 
There are $46 \%$ women are directly or indirectly related with farming in Bangladesh. Women also participate in a wide range in crop cultivation and fisheries and others agricultural activities. Women also spend most of their time in preharvesting with the average time in home gardening being 68 hours per week [11]. Sometimes women are more effective in harvesting of vegetables than man. In case of homestead gardening mostly women spend their much time because men are busy with outside work.

A number of three agricultural sector has increased over time between 1999/2000 and 2005/06, the proportion of women in the agricultural labor force increased from less than $20 \%$ to $33.6 \%$ of the total [12]. Though female has a significant contribution to productivity and technical efficiency as agricultural labor [13], gender discrimination exist in the labor market economical employment of labor remains skewed in favor of men [14]. A large number of women has entered in the labor force but not been treated as equals to men. They earn less than men and have less opportunity for growth [15]. Because of limited control and ownership of productive physical and human capital, women's ability to generate income in the agricultural sector is severely constrained. Bangladeshi women are disadvantaged relative to men regarding assets brought to marriage [16], productive assets such as land, livestock and agricultural machinery [17] and human capital [18], show that lack of education in adult women in Bangladesh is strongly correlated with extreme poverty, $80 \%$ of adult women with no education live below half a dollar a day.

The condition of women employment in agricultural sector in the northern Bangladesh has been changed a lot, from unpaid family labor to paid farm workers [19]. According to the last census in 2011, Chapainawabganj district had a population of 1,647,521. Among them, 837,303 were female and their literacy rate were $44.3 \%$. In Chapainawabganj district, women have been engaged with agriculture mostly as family labor since long time. But, due to center based rapid urbanization and industrialization, swift out-migration of men [20] and commercialization of vegetable farming in northern Bangladesh [21], lacking of labor has been emerged. Such labor scarcity has created more work field for women as economically active participants in agriculture and consequently as a result the women have started working in the agricultural fields where men were used to be. Women have always been granted secondary role in the family and society. Women are aware of gender inequalities and are trying to fight them [22]. More participation of women in the agricultural fields has created a new era in the northern districts in which women's role in agriculture is shifting from unpaid family workers to paid farm workers, a phenomenon termed as "feminization of agriculture" [23]. Reducing gender discrimination is widely recognized around the world as well as in Bangladesh contributing to agricultural growth and the attainment of food and nutritional security. This research has shown that women can lead to improvements in their status both inside and outside the household including greater control over household resources, better mental health, reduced time constraints and increased access to financial services, health care, skills development, income-earning opportunities, information about markets and legal rights all of which may, in turn, positively impact agricultural productivity, nutrition and food security by empowering. In order to achieve sustained food security, poverty alleviation in agrarian economies and rural development need to promote gender equality. Thus, the study made an attempt to comprehend the roles and extent of women's engagement in agriculture and to evaluate their empowerment attainment considering their increasing participation as economically active participants in the agriculture sector of four selected village in Chapainawabganj district of Bangladesh.

Although most of the women of Chapainawabganj are enjoying some domestic empowerment, they are unable to make their own decision which lead them to low empowerment [24]. However, the factors affecting the proper development of women of the northern part of the country are still unidentified. We therefore analyzed the empowerment level of the women achieved through agricultural activities and the constraints for which women are lagging behind. The following objectives have been established to guide the study:

1. To identify the socio-demographic characteristics of the respondents;

2.To ascertain the level of women empowerment in the study area;

3. To determine the contribution of selected characteristics of the respondents towards women empowerment.

\section{Methodology}

\section{A. Research Design}

The present study was a descriptive survey research (A type of research that describes a population situation or phenomenon that is being studied). This study purposively selected 4 villages in Chapainawabganj district where economically active women in agriculture were available. The study used the simple random sampling technique to select 120 respondents (women) to collect data using household survey. Face to face interview method was used to collect data from the respondents using a pre-structured questionnaire. Primary data were collected during the period of December 2020 to January 2021. By using the prepared interview schedule, primary information was collected regarding the respondent's age, education, land ownership and land size, per day income as a laborer, membership in social organizations, production and household decision making, Constraints in agricultural participation, Attitude of the respondents etc.

\section{B. Variables and Their Measurement}

The independent variables of the study which influenced the respondent's opinion are age, educational status, family size, cultivable land, land ownership, monthly income, family member, number of children, farming experience, extension contact, and cosmopolitan behavior. Age of a respondents is measured in terms of actual years on the basis of their statement. Educational status was measured by the number of years of schooling and it was further categorized as illiterate (0), primary (1-5), secondary (6-10), tertiary (>10) on the basis of statement of the respondents [25]. Family size referred to the total number of members of a 
family including the respondent herself, husband, children and other permanent dependent who lived together as family unit. Monthly income of the respondents was measured in Bangladeshi taka (BDT) on the basis of total yearly earning from agricultural and non- agricultural sources of their family. Respondents farming experience was categorized into low ( $<10$ years), medium (10-20 years) and high $(>20$ years). This classification was in conformity with Haq (2000) and Ahmed (1995) [26], [27].

\section{Measurement of Women Empowerment}

Women empowerment of the study area was measured using 4 indices [28].

Index 1: Decision making ability: The ability to select between two or more alternatives to reach the best outcome in the shortest time. The respondents were asked whether they can make their own decision or not with a close question having "Yes" and "No" option. Binary dependent variable assigned with value " 1 " for respondents said "Yes" and " 0 " for "No".

Index 2: Educational Rights: Educational right is defined by which recognizes a right to free, compulsory primary education for all, an obligation to develop secondary education accessible to all, on particular by the progressive introduction of free secondary education as well as higher education also. The respondents were asked, they got education opportunity like men or not with a close question including "Yes" or "No" option. Binary dependent variable assigned with value " 1 " for "Yes" and " 0 " for "No".

Index 3: Economic participation: The economic participation of women refers to the presence of women in the workforce in quantitative terms. It is important not only for decreasing the levels of poverty among women, but also raising household income and encouraging economic development of the whole countries. Economic participation concerns with the numbers of women participating in the labor force comparing with male. The respondents were asked, they participate in income generating activities like men or not with a close question including "Yes" or "No" option. Binary dependent variable assigned with value " 1 " for Yes and " 0 " for "No".

Index 4: Economic opportunity: It concerns the quality of women's economic involvement, rather than their poor number of presences as workers because of remuneration on an equal basis [28]. This is a particularly serious problem in developing countries, where women may gain employment with relative comfort, but where their employment is either concentrated in poorly paid or unskilled job because the absence of upward mobility and opportunity. In this case the respondents asked about their per day income as a labor and about their payment system comparing with men. The participants were asked they got equal payment as like as men or not with a close question including "Yes" or "No" option. Binary dependent variable, assigned with value " 1 " for Yes and " 0 " No. In the research area generally per day income for men was $>350$ Taka (BDT). Women getting less than 350 Taka (BDT) was considered as economically undervalued.

Women empowerment was measured by summing the score of above four indices. The computed score ranged from " 0 " to " 4 " where " 4 " indicating high empowerment and "o" indicating low empowerment. The sum value of four indices is divided into three categories at an equal split and named as low empowerment $(<1.32)$, medium empowerment (1.332.65) and high empowerment (>2.66).

\section{Measurement of Attitude of the Respondents towards Women Empowerment}

Respondent's attitude has been measured by constructing a 5- point Likert type scale [29]-[30]. A 5-point scale consisting of 10 items (statements) on women empowerment through agriculture was constructed for this purpose. A respondent was asked to express her extent of agreement or disagreement by checking against any of the five attitudes and scoring was assigned as i) strongly agree (5), ii) agree (4), iii) no opinion (3) iv) disagree (2) and v) strongly disagree (1) and alternatively for negative statements [31][32].

Attitude score of the respondents on women empowerment through agriculture was obtained by adding together scores on all the 10 items presented in the interview schedule. Thus, attitude score of a respondent on women empowerment could from 10 to 50, where 10 indicates low favorable attitude and 50 indicates highly favorable attitude. The sum value of ten items (statements) divided into three categories at an equal split and named as 'low favorable attitude' (10-23), 'moderately favorable attitude' (24-36) and 'highly favorable attitude' (37-50).

\section{E. Data Analysis}

Necessary coding of data was done after collecting the data and transferred these into computers for analysis. Different analyses like frequency count, means, range with percentage and categories were administered utilizing Statistical Package for Social Science (SPSS) to show the contribution of demographic characteristics and income generating activities of the respondents and then had made different chart from that data using excel. Multiple regression analysis was used for exploring the influence of independent variables on dependent variables.

\section{RESULTS AND DISCUSSION}

\section{A. Respondents Socio-demographic Characteristics}

Data presented in table 1 indicated that the highest proportion $(83.3 \%)$ of the respondents were in the middle (29 to 52 years) age with an average of 37.38 , where $10.0 \%$ of the respondents belong to young $(<29$ Years) age and the old (>52years) age were $6.7 \%$. Majority of the respondents $(60.0 \%)$ were illiterate. The data further reveals that $26.7 \%$ of the respondents from primary level and $13.3 \%$ respondents from secondary level with an average of 1.81 . There are no respondents from tertiary level. Hence, we can easily say that the illiteracy rate was too high in the study area. Most of the respondents had small sized family $(56.7 \%)$ which contained up to 4 members, some of them had medium sized family $(41.7 \%)$ which contained 5 to 8 members and the large family $(1.7 \%)$ contained $>8$ members with a mean of 4.35 . Most of the respondents $(51.7 \%)$ had 3-5 numbers of children, followed by up to 2 children ( $45 \%$ ) and more than $>5$ number of children of $3.3 \%$ respectively with a mean of 2.68 . 
TABLE I: DISTRIBUTION OF THE RESPONDENTS ACCORDING TO THEIR SOCIO-DEMOGRAPHIC CHARACTERISTICS (N=120)

\begin{tabular}{|c|c|c|c|c|}
\hline Variable & Categories & Frequencies & Percentage & Mean \\
\hline \multirow{3}{*}{ Age } & Young (<29 Years) & 12 & 10.0 & \multirow{3}{*}{37.38} \\
\hline & Middle ( 29 to 52 years) & 100 & 83.3 & \\
\hline & Old(>52years) & 8 & 6.7 & \\
\hline \multirow{4}{*}{ Education } & Illiterate $(0)$ & 72 & 60.0 & \multirow{4}{*}{1.81} \\
\hline & Primary $(1-5)$ & 32 & 26.7 & \\
\hline & Secondary $(6-10)$ & 16 & 13.3 & \\
\hline & Tertiary $(>10)$ & 0 & 0 & \\
\hline \multirow{4}{*}{$\begin{array}{c}\text { Family } \\
\text { Members }\end{array}$} & Up to 4 & 68 & 56.7 & \multirow{3}{*}{4.35} \\
\hline & $5-8$ & 50 & 41.7 & \\
\hline & $>8$ & 2 & 1.7 & \\
\hline & Up to 2 & 54 & 45 & \multirow{3}{*}{2.68} \\
\hline \multirow[t]{2}{*}{ No. of Children } & $3-5$ & 62 & 51.7 & \\
\hline & $>5$ & 4 & 3.3 & \\
\hline \multirow{3}{*}{ Marital Status } & Married & 120 & 100 & \multirow{3}{*}{1.00} \\
\hline & Unmarried & 0 & 0 & \\
\hline & Small ( $<2$ acre $)$ & 112 & 93.3 & \\
\hline \multirow[t]{2}{*}{ Land Size } & Medium (2-5 acre) & 8 & 6.7 & \multirow{2}{*}{0.38} \\
\hline & High ( $>5$ acre) & 0 & 0 & \\
\hline \multirow{4}{*}{ Cultivable land } & Own & 8 & 6.7 & \multirow{4}{*}{3.25} \\
\hline & Lease & 28 & 23.3 & \\
\hline & Khas & 10 & 8.3 & \\
\hline & Others land & 74 & 61.7 & \\
\hline \multirow{3}{*}{$\begin{array}{c}\text { Land } \\
\text { Ownership }\end{array}$} & Own & 0 & 0 & \multirow{3}{*}{ - } \\
\hline & Family & 8 & 6.7 & \\
\hline & Others & 112 & 93.3 & \\
\hline \multirow{3}{*}{$\begin{array}{l}\text { Monthly } \\
\text { Income }\end{array}$} & Low $(<6973)$ & 6 & 5 & \multirow{3}{*}{9351.38} \\
\hline & Medium (6973-27500) & 114 & 95 & \\
\hline & High $(>27500)$ & 0 & 0 & \\
\hline \multirow{2}{*}{ Income Source } & Agriculture & 120 & 100 & \multirow{2}{*}{1.0} \\
\hline & Non-agriculture & 0 & 0 & \\
\hline \multirow{3}{*}{$\begin{array}{l}\text { Farming } \\
\text { Experience }\end{array}$} & Low $(<10$ years $)$ & 20 & 16.7 & \multirow{3}{*}{21.50} \\
\hline & Medium(11-20years) & 40 & 33.3 & \\
\hline & High $(>20$ years $)$ & 60 & 50.0 & \\
\hline Extension & Yes & 0 & 0 & \multirow{2}{*}{0.00} \\
\hline Contact & No & 120 & 100 & \\
\hline Cosmopolitan & Yes & 0 & 0 & \multirow{2}{*}{0.00} \\
\hline behavior & No & 120 & 100 & \\
\hline
\end{tabular}

All of them were married (100\%). Most of the respondents (93.3\%) had small land $(<2$ acre), some of them $(6.7 \%)$ had medium land $(2-5$ acre $)$ with an average of 0.38 . From the sampled respondents we found that most of the respondents $(61.7 \%)$ did not have own land and they work in others land in daily payment basis. About $23.3 \%$ of the respondents works in lease land, $(8.3 \%)$ of the respondents works in government owned 'khas' land mainly for homestead and only $(6.7 \%)$ of the respondents works in their own field with an average of 3.25. Most of the respondents (95\%) had medium level of monthly income followed by low income $(5 \%)$ and high income $(0 \%)$ respectively with an average of Tk. 9351.38All of the respondents (100\%) were depended on agriculture for their income. Most of the respondents (50.0\%) had a high level of farming experience followed by low level $(16.7 \%)$ of farming experience and medium level (33.3\%) of farming experience with a mean of 21.50. From this study no extension contact was found as well as they had no tendency to go outside from their own territory means cosmopolitan behavior was absent among the respondents.

\section{B. Respondents Involvement in Agriculture}

Apart from crop production the respondents were also engaged in other activities like livestock \& poultry and homestead gardening. But from the interview, the study found that the interviewees were involved in agricultural activities entirely and side by side some of the respondents were also involved in livestock \& poultry and homestead gardening. $56.7 \% \& 21.7 \%$ of the respondents were engaged in livestock \& poultry and homestead gardening respectively alongside $100 \%$ involvement in crop production. Most of the women in the study area were engaged in cleaning, threshing, and drying (100\%) with little involvement in planting (70\%), weeding (71.7\%) and harvesting (78.3\%). Only $1.7 \%$ women were involved in marketing, but they had no involvement in land preparation $(0 \%)$ activity indicates that women are not equally considered as men in these works. About $26.7 \%$ of the respondents were involved in only post-harvest activities whether $73.3 \%$ of the respondents were involved in both the pre- and post-harvest activities but interestingly involvement is agricultural activities of the respondents during pre-harvest period is null. Most of the respondents (68.3\%) worked only as paid labor on others field followed by $31.7 \%$ worked both in their own field and others land. No one worked only in their own field.

Most of the respondents still use old technology in agricultural activities. Only $18.3 \%$ of the respondents used modern technology whereas $81.7 \%$ of the respondents used traditional technology. The respondents did not get any support in terms of seed, fertilizer \& pesticide from government or any other NGOs. All of the respondents $(100 \%)$ source of farming was own source. Regarding training exposure in agricultural activities, the study found that only $5 \%$ of the respondents received training on this while $95 \%$ of the respondents did not get any training. Most of the respondents $(73.3 \%)$ were engaged in homestead works while only $26.7 \%$ respondents were engaged in field activities. In case of extent of participation, about $68.3 \%$ respondents participated in the field activities often (90 to 100 days in a year) with $28.3 \%$ of the respondents participated in 
field regularly and $3.3 \%$ respondents participated rarely respectively. But none of the respondents was found frequent in their extent of participation. Only $31.7 \%$ of the respondents took loan from NGOs for crop production indicating lower monetary support for their development.

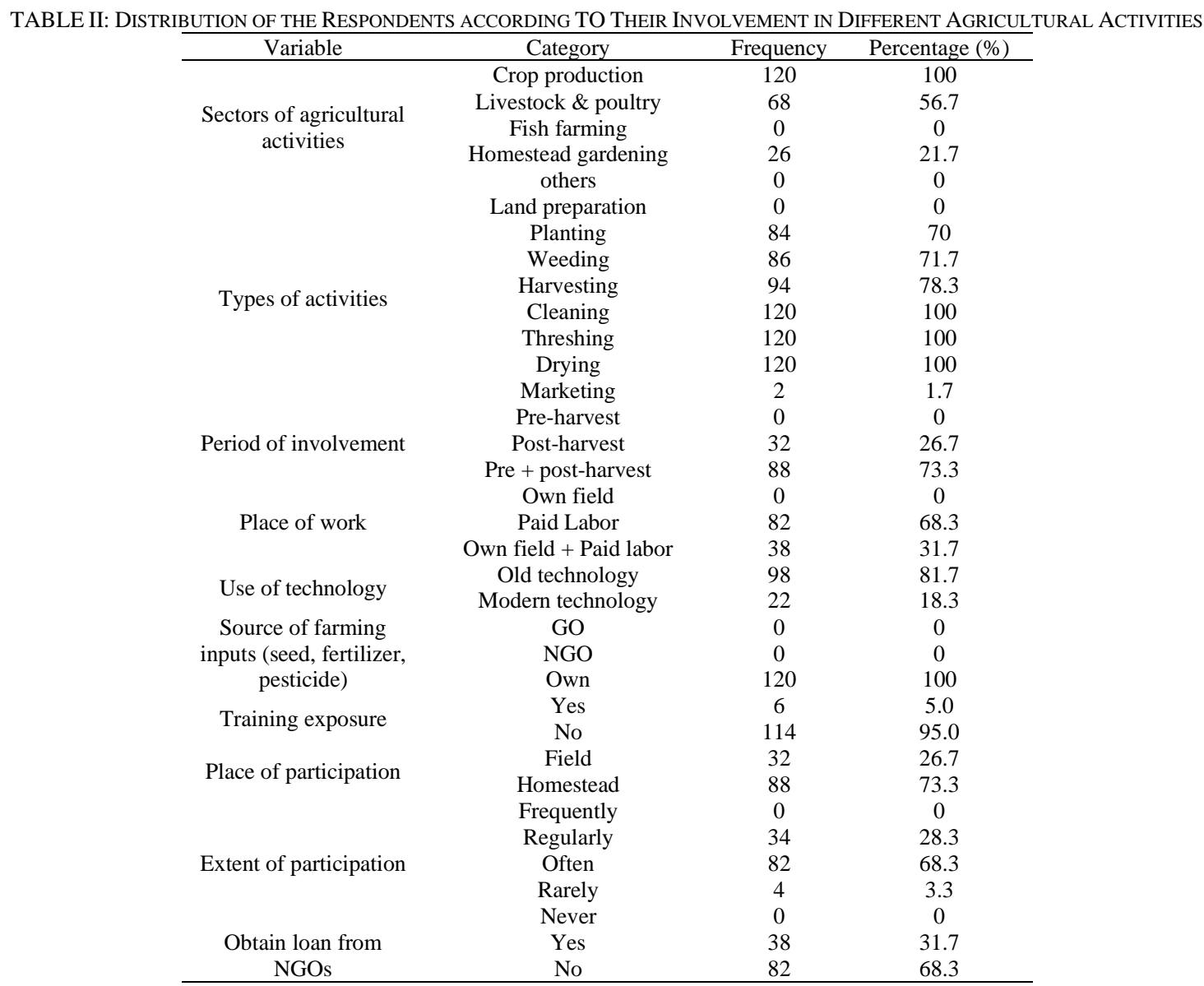

\section{Constraints in Agricultural Participation}

The constraints of the respondents in agricultural participation were identified and reported below in the Fig. 1.

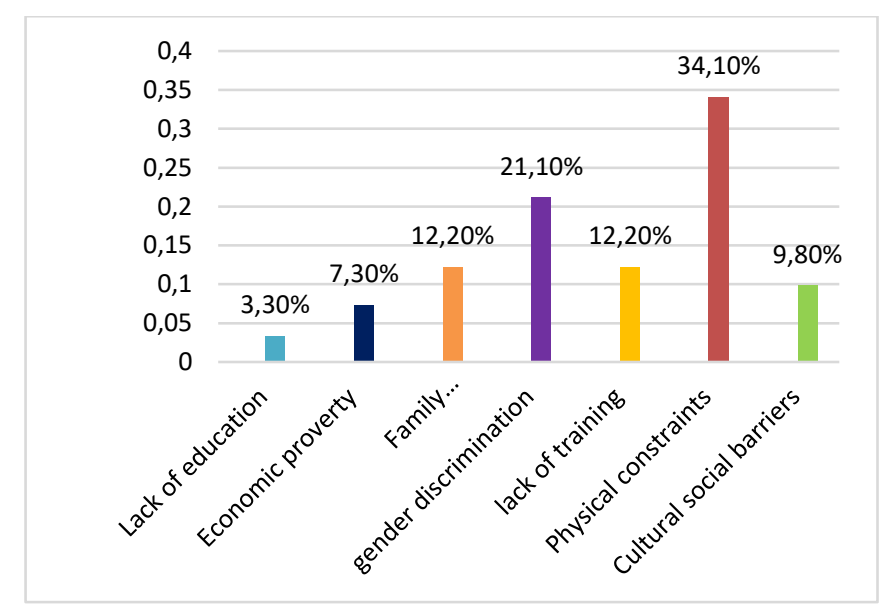

Fig. 1. Distribution of the respondents according to their constraints in agricultural participation.

The constraints of the women in participation in agricultural activities were reported as lack of education, economic poverty, family conservativeness, gender discrimination, lack of training, physical constraints and cultural and social barriers. The most significant constraint was physical constraint $(34.10 \%)$, followed by gender discrimination $(21.10 \%)$, family conservativeness $(12.20 \%)$, lack of training (12.20\%), cultural and social barriers (9.80\%) and economic poverty $(7.30 \%)$ respectively. Physical constraints develop through lack of proper nutrient, health care etc. Similar findings were also found in other studies [31], where the major obstacle of the women from rural farm families in participating in agriculture was physical constraints. Gender discriminations suppress development and has a negative effect on wellbeing of people [33].

\section{Determination of Women Empowerment}

Among the 4 indices used for computing women empowerment, economic participation scored highest. [34], conducted a study on "Women Empowerment through the Development of Micro Entrepreneurship in Rural Bangladesh" and found "Women's participation in home typed, traditional business can significantly build social capital, create awareness and enhance their capability to uplift their position". All the respondents participated in income generating activities with a mean of 1.00 , followed by $28.3 \%$ respondents could take their own decision whereas $71.7 \%$ respondents could not take their own decision with a mean of 0.33 . They also had less opportunity to get education. About $66.7 \%$ respondents had negative response to educational right with only $33.3 \%$ respondents replied positively with a mean of 0.33 , dissimilar findings were found by [35], where men prefer other women to have rights because men care about their daughter sand women rights raises investments in 
education of children. The economic opportunity of the respondents was totally 0 . This reveals that although $100 \%$ respondents were involved in economic participation, but they had no economic opportunity. Not just an individual but an entire family successfully empowered by doing work and income generating activities [36].

TABLE III: DISTRIBUTION OF THE RESPONDENTS ACCORDING TO WOMEN

\begin{tabular}{ccccc}
\multicolumn{5}{c}{ EMPOWERMENT INDICES } \\
\hline Indices & Groups & $\begin{array}{c}\text { Frequenc } \\
\mathrm{y}\end{array}$ & Percentage & $\begin{array}{c}\text { Mean } \\
\text { (Range: 0.00 to } \\
1.00)\end{array}$ \\
\hline Decision & Yes & 34 & 28.3 & 0.28 \\
making ability & No & 86 & 71.7 & 0.33 \\
Educational & Yes & 40 & 33.3 & 1.00 \\
right & No & 80 & 66.7 & \multirow{2}{*}{0.00} \\
Economic & Yes & 120 & 100 & \\
Participation & No & 0 & 0 & \\
Economic & Yes & 0 & 0 & \\
opportunity & No & 120 & 100 & \\
& & &
\end{tabular}

Women empowerment was obtained by adding together scores of all the 4 indices. Thus, score could range from 0 to 4 , where 0 indicating 'very low empowerment' and 4 is 'very high empowerment' shown in the following figure.

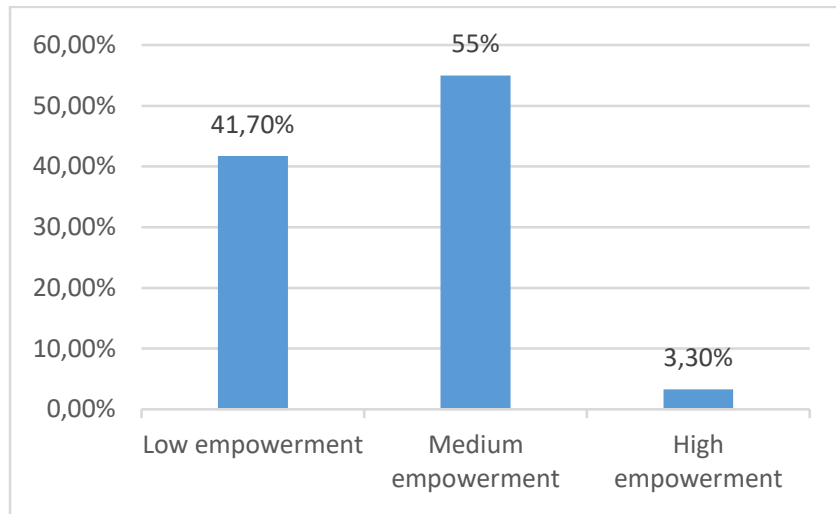

Fig. 2. Distribution of the respondents according to their level of empowerment.

From the figure 3 it is shown that most of the respondents (55\%) had medium empowerment, followed by $41.70 \%$ respondents had low empowerment and $3.30 \%$ respondents had high empowerment respectively. [24], conducted a study on "Determinants of Women Empowerment at Domestic and Non-domestic Issues: Evidence from Chapainawabganj District in Bangladesh" and found that the women of Chapainawabganj district were low empowered.

\section{E. Attitude of the Respondents to Women Empowerment}

Respondents' attitude was measured based on ten different statements and categorized according to their score which is shown in the Fig. 3.

The information of Fig. 3 reveals that highest proportion $(70 \%)$ of the respondents showed moderately favorable attitude and only $30 \%$ of the respondents showed highly favorable attitude toward women empowerment. There is no one who showed low favorable attitude to women empowerment, which indicates that women of the study area are very keen to get empowerment.

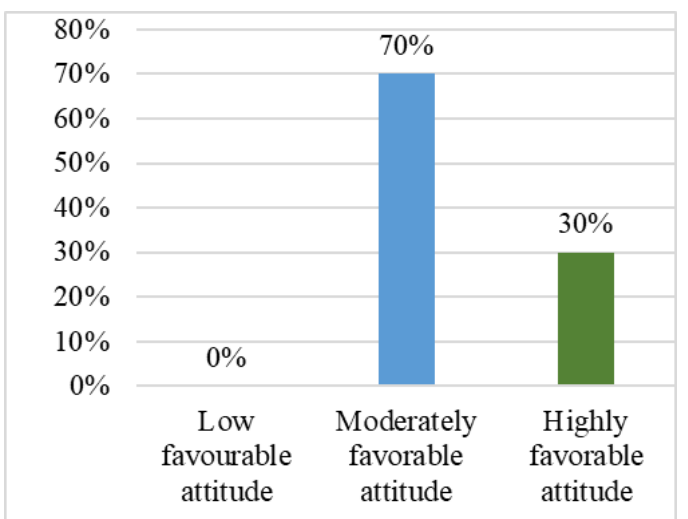

Fig. 3. Distribution of the respondents according to their attitudes towards women empowerment.

\section{F. Rank Order of the Attitude Statements}

The information of Table 4 indicates that "Women empowerment helps to develop future generation", this positive statement ranked first with a score of 486 followed by "Education is not necessary for agricultural activities" which is a negative statement, and its score was 462. The negative statement "Present situation is not suitable for women involvement in agriculture" ranked the last and its score was 314.

TABLE IV: RANK ORDER OF THE STATEMENTS ACCORDING TO THEIR

\begin{tabular}{|c|c|c|c|c|}
\hline SL No & Statements & Score & Average & Rank \\
\hline 1. & $\begin{array}{c}\text { Involvement in agricultural } \\
\text { activities improve social status }(+) \\
\text { Involvement in agricultural }\end{array}$ & 402 & 3.35 & 8 \\
\hline 2. & activities improve economic status & 440 & 3.67 & 5 \\
\hline 3. & $\begin{array}{c}\text { Life standard improves through } \\
\text { agricultural activities }(+)\end{array}$ & 458 & 3.81 & 3 \\
\hline 4. & $\begin{array}{l}\text { Involvement in agricultural } \\
\text { activities improve help to } \\
\text { understand their right in society } \\
\text { (+) }\end{array}$ & 412 & 3.43 & 7 \\
\hline 5. & $\begin{array}{c}\text { Present situation is not suitable for } \\
\text { women involvement in agriculture } \\
(-)\end{array}$ & 314 & 2.62 & 10 \\
\hline 6. & $\begin{array}{c}\text { Gender discrimination fades away } \\
\text { through women participation in } \\
\text { agriculture }(+)\end{array}$ & 364 & 3.03 & 9 \\
\hline 7. & $\begin{array}{c}\text { Education is Not necessary for } \\
\text { agricultural activities (-) }\end{array}$ & 462 & 3.85 & 2 \\
\hline 8. & $\begin{array}{l}\text { Agricultural involvement } \\
\text { improves decision making ability } \\
(+)\end{array}$ & 444 & 3.70 & 4 \\
\hline 9. & $\begin{array}{l}\text { Women empowerment helps to } \\
\text { develop future generation }(+)\end{array}$ & 486 & 4.05 & 1 \\
\hline 10. & $\begin{array}{l}\text { Government can play important } \\
\text { role in women empowerment }(+)\end{array}$ & 438 & 3.71 & 6 \\
\hline
\end{tabular}

G. Contribution of Selected Characteristics of the Respondents on Women Empowerment

Regression results in Table 4 indicated that two out of nine characteristics were statistically significant predictors: 1) age 2 ) education. The women who retained one or more of these characters at a higher level were found to have higher women empowerment. These variables together explained $21 \%$ of the variance of effective factors on women empowerment. 
TABLE V: RESPONDENTS' CHARACTERISTICS AND THEIR CONTRIBUTION ON WOMEN EMPOWERMENT

\begin{tabular}{cccc}
\hline $\begin{array}{c}\text { Characteristics of the } \\
\text { respondents }\end{array}$ & Coefficient b & $\mathrm{t}-$ value & $\mathrm{p}$ (significant) \\
\hline Age $* *$ & .514 & 2.746 & .008 \\
Family size & -.015 & -.113 & .910 \\
Education** & .400 & 3.000 & .004 \\
Number of children & -.157 & -1.080 & .285 \\
Monthly Income & -.029 & -.220 & .826 \\
Farming experience & -.263 & -1.524 & .134 \\
Land size & -.082 & -.610 & .545 \\
Land ownership & -.216 & -1.621 & .111 \\
Attitude & .084 & .701 & .486
\end{tabular}

Note: $\mathrm{R}=0.57, \mathrm{R}^{2}=0.33$, Adjusted $\mathrm{R}^{2}=0.21$, Critical Value of $\mathrm{F}=2.76$, and ${ }^{*} \mathrm{p}<0.05,{ }^{* * *} \mathrm{p} \leq 0.001$.

The result of the regression table shows a positive and significant (at $1 \%$ level) contribution of age on women empowerment. Age is proportionally related with women empowerment. The study depicts that women who were aged have better decision making ability than younger women, similar findings were also found in other studies [25], [37], [38], where aged women have better decision making ability than younger women. Alongside increasing of age of women they grow and have better decision making ability. So, the more the age increase the more the women become empowered.

Respondents education showed a positive and significant (at $1 \%$ level) contribution on women empowerment. Similar types of results were also obtained by [25], [29]. It means that the higher the level of education of the respondents, the higher their empowerment. Education helped to gain knowledge and thus increase their power of understanding. Consequently, their outlook was broadened, and horizon of knowledge was expanded. The real and outer world is exposed to an educated man and he can gain various experiences for perceiving a thing better [39]. Education provides information to women about their rights, household decision making, self-confidence, respect for others' advice and information and freedom in voting [40].

\section{CONCLUSIONS}

Based on above analysis, it is found most of the respondents were middle age, illiterate, belonged to small size family. Agriculture is the main occupation among the respondents. Most of the respondents were found without own land although they continue their livelihood mostly by crop production, livestock rearing and day laboring. Most of them were deprived from educational right, help from GO or NGO or all kind of agricultural training and they had no cosmopolitan behavior. They take lease of cultivable land from others. The economic participation rate of the respondents was very high, on the other hand they had no economic opportunities. About $95 \%$ of the respondents were under medium income category with high farming experience. Most of them were unable to make their own decision. The main constraints in agricultural participation were their physical weakness that indicates lack of proper nutrition. The attitude of the participant's towards women empowerment were moderately favorable. Finally, the research confirmed that the level of empowerment of the women of Chapainawabganj through agriculture was medium.

\section{REFERENCES}

[1] N. Kabeer, "Gender equality and women's empowerment: A critical analysis of the third millennium development goal 1," Gender \& Development, vol. 13, no. 1, pp. 13-24, 2005.

[2] E. Bayeh, " The role of empowering women and achieving gender equality to the sustainable development of Ethiopia," Pacific Science Review B: Humanities and Social Sciences, vol. 2, no. 1, pp. 37-42, 2016.

[3] N. I. Hoffmann and A. Roscoe, "Investing in women along agribusiness value chains," The World Bank, 2016.

[4] BBS, Yearbook of Agricultural Statistics in Bangladesh, Bangladesh: Bangladesh Bureau of Statistics (BBS), 2016, p. 98.

[5] S. S. Hasan, A. Mohammad, M. K. Ghosh and M. I. Khalil, "Assessing of farmers' opinion towards floating agriculture as a means of cleaner production: A case of Barisal district, Bangladesh," Current Journal of Applied Science and Technology, vol. 20, no. 6, pp. 1-14, 2017.

[6] S. S. Hasan and S. Sultana, "Food and Economic Security through Homestead Vegetable Production by Women in Flood Affected Char Land," The Agriculturists, vol. 9, no. 1-2, pp. 44-53, 2011. http://dx.doi.org/10.3329/agric.v9i1-2.9478.

[7] S. Sultana and S. S. Hasan, "Impact of micro-credit on economic empowerment of rural women," The Agriculturists, vol. 8, no. 2, pp. 43-49, 2010.

[8] M. Hoque and Y. Itohara, "Participation and decision making role of rural women in economic activities: A comparative study for members and non-members of the micro-credit organizations in Bangladesh," Journal of Social Sciences, vol. 4, no. 3, pp. 229-236, 2008.

[9] S. S. Hasan, M. Hossain, S. Sultana and M. K. Ghosh, "Women's involvement in income generating activities and their opinion about its contribution: A study of Gazipur District, Bangladesh," Science Innovation, vol. 3, no. 6, pp. 72-80, 2015.

[10] S. Zaman, "Women's Role and Status in Bangladesh Agriculture," Human Development Research Centre (HDRC), Dhaka, 2002.

[11] S. Akhter, M. Alamgir, M. S. I. Sohel, M. P. Rana, S. M. Ahmed and M. S. H. Chowdhury, "The role of women in traditional farming systems as practiced in homegardens: a case study in Sylhet Sadar Upazila, Bangladesh," Tropical Conservation Science, vol. 3, no. 1, pp. 17-30, 2010.

[12] M. Asaduzzaman, "The next agricultural transition in Bangladesh: Which transition, why and how?," in conference on Understanding the Next Generation, Asia, Bangkok, 2010, April 23.

[13] S. Rahman, "Women's labour contribution to productivity and efficiency in agriculture: empirical evidence from Bangladesh," Journal of Agricultural Economics, vol. 61, no. 2, pp. 318-342, 2010.

[14] H. Zaman, "Patterns of activity and use of time in rural Bangladesh: class, gender, and seasonal variations," The Journal of Developing Areas, vol. 29, no. 3, pp. 371-388, 1995.

[15] C. Goldin, Understanding the gender gap: An economic history of American women, USA: Oxford University Press, 1994, pp. 17-26.

[16] A. R. Quisumbing and J. A. Maluccio, "Resources at marriage and intrahousehold allocation: evidence from Bangladesh, Ethiopia, Indonesia, and South Africa," Oxford Bulletin of Economics and Statistics, vol. 65, no. 3, pp. 283-327, 2003.

[17] A. Quisumbing, S. Roy, J. Njuki, K. Tanvin and E. Waithanji, "Can dairy Value Chain Projects Change Gender Norms in Rural Bangladesh? Impacts on Assets, Gender Norms, and Time Use," International Food Policy Research Institute, Washington DC.

[18] A. U. Ahmed, M. A. R. Quisumbing, J. Hoddinott, M. Nasreen and E. Bryan, "Relative efficacy of food and cash transfers in improving food security and livelihoods of the ultra-poor in Bangladesh," World Food Programme, Bangladesh, 2007.

[19] D. H. Galhena, R. Freed and K. M. Maredia, "Home gardens: a promising approach to enhance household food security and wellbeing," Agriculture \& food security, vol. 2, no. 8, pp. 25-37, 2013.

[20] R. Afsar, Internal migration and development nexus: The case of Bangladesh, Dhaka, Bangladesh: University Press Limited, 2003.

[21] S. Nazneen, N. Hossain and M. Sultan, "National discourses on women's empowerment in Bangladesh: continuities and change," International Development Studies, vol. 3, no. 7, pp. 17-23, 2011.

[22] R. L. Panigraphy and D. Bhuyan, Women Empowerment, India: Discovery Publishing House, 2006. 
[23] W. M. H. Jaim and M. Hossain, "Women's participation in agriculture in Bangladesh 1988-2008: Changes and determinants. In Preconference event on dynamics of rural livelihoods and poverty in South Asia," in 7th Asian society of agricultural economists (ASAE) international conference, Hanoi, Vietnam., October, 2011.

[24] M. Rahman, U. K. Karmaker and A. R. Mia, "Determinants of women empowerment at domestic and non-domestic issues: Evidence from Chapai Nawabganj district in Bangladesh," Dhaulagiri Journal of Sociology and Anthropology, vol. 3, pp. 143--162, 2009.

[25] M. K. Ghosh, A. A. Shoily, M. S. Islam, U. M. Misu and M. A. Khatun, "Assessing the Participation of Indigenous Santals People in Chapainawabganj District of Bangladesh in Income Generating Activities," The Agriculturists, vol. 18, no. 1, pp. 137-143, 2020.

[26] H. Huq, "People's Perception: Exploring Contestation, Counterdevelopment and Rural livelihoods: Cases from Muktinagar, Bangladesh," Wageningen, Netherlands, 2000.

[27] M. B. Ahmed, "Identification of farmers communication behavior and nature of information exchange during BS farmers interaction in selected area of Dinajpur Sadar thana,"Unpublished MS Thesis, Dept. of AER, IPSA, Bangladesh, 1995.

[28] N. P. A. Azeez and S. M. J. Akhtar, "Women Empowerment: A Study Based on Index of Women Empowerment in India," International Journal of Research in Commerce, Economics \& Management, vol. 2, no. 5 , pp. 119-125, 2020.

[29] S. Saha, S. S. Hasan, M. E. Haque and T. Ahamed, "Perception Based Assessment of Ecosystem Services of Madhupur Sal Forest in Bangladesh," European Journal of Agriculture and Food Sciences, vol. 3, no. 1, pp. 39-44, 2021.

[30] M. K. Ghosh and S. S. Hasan, "Farmers' attitude towards sustainable agricultural practices," Bangladesh Research Publications Journal, vol. 8, no. 4, pp. 227-235, 2013.

[31] S. S. Hasan, M. Z. Turin, M. K. Ghosh and M. I. Khalil, "Assessing Agricultural Extension Professionals Opinion towards Sustainable Agriculture in Bangladesh," Asian Journal of Agricultural Extension, Economics and Sociology, vol. 17, no. 1, pp. 1-13, 2017. http://dx.doi.org/10.9734/AJAEES/2017/33338.

[32] S. S. Hasan, M. E. Haque, I. Z. Suchi and M. A. Hossain, "Assessment of Diploma Agricultural Students' Attitude towards Educational Sustainability: A Study of Selected Agricultural Training Institutes of Bangladesh," Journal of Education, Society and Behavioural Science, $\begin{array}{llllll}\text { vol. } 25, & \text { no. } & 2, & \text { pp. } & 1-12, & 2018\end{array}$ http://dx.doi.org/10.9734/JESBS/2018/41170.

[33] G. Tharani, M. S. R. Akther and N. Ananthini, "Assessment of women participation in agriculture in Vavuniya district, Sri Lanka," International Journal of Social Sciences and Managemen, vol. 3, no. 3, pp. 159-162, 2016

[34] World Bank, "Engendering Development: Through Gender Equality in Rights, Resources, and Voice," The World Bank, Washington DC, Research Report, 2001.

[35] B. Sultana, Z. B. Zaaba and K. Umemoto, "Women's empowerment through the development of micro entrepreneurship in rural Bangladesh," Social Science, vol. 5, no. 1, pp. 1-9, 2010.

[36] M. Doepke and M. Tertilt, " Women's Liberation: What's in it for Men?," The Quarterly Journal of Economics, vol. 124, no. 4, pp. 15411591, 2009.

[37] E. Becker, "Themes from Feed the Future Women's Empowerment in Agriculture Index: Report from Qualitative Case Studies in Bangladesh, Guatemala, and Uganda," Washington DC, Unpublished report submitted to the International Food Policy Research Institute, 2012.

[38] M. S. Haque, R. Akter and K. Laoubi, "Effectiveness of community based organization (CBO) microcredit programme of concern worldwide: A case study of Bangladesh," African Journal of Business Management, vol. 5, no. 24, pp. 10101-10107, 2011.

[39] M. K. Ghosh, S. S. Hasan, M. E. Haque and M. J. Uddin, "Knowledge of farmers to sustainable agriculture practices: A case study in Southwestern region of Bangladesh," Scholars Journal of Agriculture and Veterinary 2020. http://dx.doi.org/10.36347/sjavs.2020.v07i01.002.

[40] S. Mahmud, N. M. Shah and S. Becker, "Measurement of women's empowerment in rural Bangladesh," World development, vol. 40, no. 3, pp. 610-619, 2012. 